\title{
黒毛和種種雄牛の産肉能力評価に関する 現場後代検定の試み
}

\author{
橋口勉・前田芳實・魔島 学*. \\ 田之上悠石* \\ 鹿児島大学譨学部, 鹿児島市 890 \\ *鹿览島県畜産試験場，国分市 899-44
}

(1982. 3. 26 受付)

\begin{abstract}
要 約 1978。年から 1979 年の 2 年間に躈児島県の農家で肥育された 3,431 頭の肥育成績に基づいて, 黑毛和種種雄牛の産肉能力評価関する現場後代檢定の可能性について検副を行なった. 10 頭以上の肥

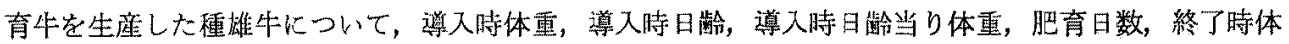
重, 1 日平均堌体量, 脂肪交雑於よびロース志面積のいずれの産肉形質においても種雄牛間差が認めら れ，1\%水準で有意であった. 脂肪交雑および 1 日平均增体量に関して種雄牛の謤価老偏差值により行な い, 4 つのダループに分類した. 分析された 7 形質に関する遺伝率のうち, 導入時体重, ロース芯面積お よび脂肪交雑は, それぞれ $0.4 \sim 0.6 ， 0.5 \sim 0.6$ おび $0.3 \sim 0.5$ と評価され, 年次間で比較的安定した 遗伝率を示したが，その他の形質の遺伝率は低く年次問でかなり異なる值究示した. 1978 年と 1979 年 の 2 年間汇共通江用いられた種雄牛について，各形質に関する種雄牛の順位相関を分析した結果，導入 時体重，脂肪交雑扩よびロース芯面積で $0.609 ， 0.765$ およよ゙゙ 0.767 を示し $1 \%$ 水淮で有意であった。脂 肪交雑と 1 日平均增体量との顋伝相関は一 -0.35 , 父平均值間の相関は -0.29 で筫の関係定した. 1 日 平均增体量と肥育日数とは，遗伝相関で -0.79 の負の高い相関が双られた。 一一芯面積と肥育日数な

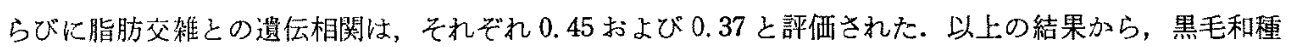
種雄牛の産肉能力評価について，一般農家の肥育データに基づく現場後代検定が可能であることが示さ れた.

日蓄会報，53(10)：656-663，1982
\end{abstract}

種雄牛の評価性，通常後代検定により行なわれるが， その检定精度怯子群の多少と检定環膛の斉一化の程度に より左右される。肉用牛の後代检定は大きく分けて施設 内検定之現場榆定に分けられるが，いずれもそれぞれ利 点と矢点がある。余められた检定所で実施する施設内检 定は，一定の飼息環境下で経済能力を比較するため，湩 雄牛の遭伝的能力の差が現われやすい反面, 施設や経費 の面から子牛の検定頭数が制約され検定精度を低好るお それがある。さらに一般農家では不可能なすぐれた旅設 および飼養管理のもとで行なわれる施設内㭘定は，遺伝 と環境の相互作用の点加らもいくつかの問题がある. 一

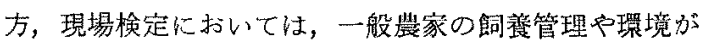
異なるため検定精度を低める不利な点はあるが，反面， 現場检定の長所梳数多くの子牛の記鈈を利用寸ることが 可能で，さらに一般農家で普及している飼養方法のもと において梌定される利点があげられる。
黒毛和種種雄牛の産肉能力の評価については, これ宋 で主として施設内検定による部分が多く，現場後代検定 の俸施についてはまだ十分な努力が払われていないのが 現状である。一般農家から収集される産肉成縝データに ついてはいくつかの問題を抱えながらる，今後は現場の 肥育データを它積極的に活用し，種雄牛評価のための育種 情報として生か寸必要があうう。

本研究柱, 鹿児島県の農家に招いて肥育され枝肉評価 の行なわれたデータを使用して，鹿児島県におけ五黑毛 和種の産肉能力の実態を明ら加にするとともに，種雄牛 の産肉能力の評価を行ない，黑毛和種の現場後代検定の 可能性について検討したむのである.

\section{材料および方法}

材料には，1978 年 1 月から 1979 年 12 月をでの 2 年間 にわたって鹿児島県下の各地区農協加ら出荷され，南九 


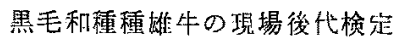

州畜産興業株式会社で屠殺解体され枝肉評俩が行なわれ た黒毛和種雄去驾牛 3, 431 頭（1978 年：1,742 頭，1979 年：1,689 頭）の肥育成績が用いられた（表 1 ). 調査項 目としては, 導入時体重, 導入時日齡, 導入時日觜当り 体重, 肥育月数, 終了㭙体重, 1 日平均增体盟, 脂肪交 雑およびロース恕面積をとりあげた。脂肪交雑およびャ 一ス芯面積の評洒は，冷署体により第 6 籁7肋骨間切 断で行なわれた.

Table 1. Number of samples

\begin{tabular}{ccc}
\hline Year & $\begin{array}{l}\text { No. of } \\
\text { steers }\end{array}$ & $\begin{array}{l}\text { No. of bulls with more } \\
\text { than ten steer progenies }\end{array}$ \\
\hline 1978 & 1742 & 45 \\
1979 & 1689 & 44 \\
\hline
\end{tabular}

遗伝的パラメーターの誄価にあたっては，各年次ごと に半兄弟の肥育牛を 10 頭以上有する種雄牛についての データをとりるとね。1978年格よび1979年の雨年次 にわたって評価された種雄牛 32 頭については、それぞれ の形咓について雨年次の順位相関係数の推定を行なっ た。遺伝率および遺伝相関は，父親分散成分により計算

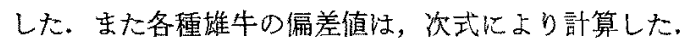

$$
\begin{aligned}
& D=10 \times\left(X_{i}-\bar{x}\right) / s+50 \\
& \text { ここて } \\
& D: \text { 偏差值 } \\
& X_{i}: \quad i \text { 番目の種雄牛の成續 }
\end{aligned}
$$

\author{
$\bar{x}$ : 全種雄牛の平均值 \\ $s:$ 標準偏差
}

全ての計算は，鹿児島大学大型電子計算機室 MELCOM-COSMO 800 III で処理した.

\section{結果}

\section{1. 産肉諸形質の年次别推移}

筆者らがこれまで分析してきた鹿児島県における肥育 牛の座肉諸形質の成續1.2)(1973 1977 年) と今回の分析

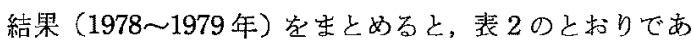
古.

まず尊入時体重についてみると，263 kg〜275 kg の範 囲で年次間の变動がみられるが，年次の推移に伴う一定 の傾问は認められない，導入時日歯令は，1974 年で261日 であったのが 1978 年では 283 日と約 22 日間遅れており， また1979年では幾分早くなっている600全体的には 遅れる傾向がみられる，導入時日歯当り体重は，1975 年 以後年次とともに徐々に低下する倾向にあるが，これは 導入時日齢の㢑孔にもかかからず導入時体重に增加がる られないことによるあのである。

肥育日数怯，年次とともに著しく延長する傾向にあ り，1973年で 377 日であったのが1979年では 493 日と なっており，116日子延長している.これに伴い終了時体 重もわずかに增加の傾向がみられる。しかし1日平均增 体量枯，肥育日数の延長にくらべ終了時体重の堌加がお もわしくないため当然のことながら低下の傾向にある。

Table 2. Meat production performance of Japanese Black Cattle steers in each year

\begin{tabular}{lccccccc}
\hline Year & $1973^{2)}$ & $1974^{2)}$ & $1975^{21}$ & $1976^{2)}$ & $1977^{27}$ & 1978 & 1979 \\
No. of steers & 420 & 726 & 608 & 381 & 884 & 1742 & 1689 \\
\hline Initial weight (kg) & 274.9 & 262.6 & 262.9 & 266.0 & 267.7 & 271.7 & 266.5 \\
Age at beginning of & $\pm 26.2^{13}$ & \pm 27.0 & \pm 28.8 & \pm 24.5 & \pm 29.4 & \pm 27.3 & \pm 25.8 \\
fattening (days) & 271.7 & 261.4 & 264.9 & 271.3 & 277.3 & 282.9 & 276.5 \\
& \pm 17.5 & \pm 16.9 & \pm 18.4 & \pm 31.4 & \pm 30.8 & \pm 30.5 & \pm 32.1 \\
Initial weight per age (kg) ${ }^{8)}$ & 0.906 & 0.995 & 1.015 & 0.991 & 0.987 & 0.969 & 0.972 \\
& \pm 0.09 & \pm 0.10 & \pm 0.11 & \pm 0.12 & \pm 0.13 & \pm 0.13 & \pm 0.12 \\
Period of fattening (days) & 377.3 & 397.6 & 441.0 & 440.4 & 462.6 & 483.0 & 492.6 \\
& \pm 33.2 & \pm 32.5 & \pm 41.6 & \pm 49.1 & \pm 59.5 & \pm 53.3 & \pm 49.3 \\
Final weight (kg) & 545.5 & 548.8 & 563.2 & 567.8 & 584.3 & 578.0 & 595.4 \\
Daily gain during period of & \pm 34.0 & \pm 42.5 & \pm 44.2 & \pm 45.6 & \pm 52.1 & \pm 47.6 & \pm 48.2 \\
fattening (kg) & 0.737 & 0.723 & 0.679 & 0.691 & 0.703 & 0.640 & 0.672 \\
& \pm 0.10 & \pm 0.10 & \pm 0.99 & \pm 0.11 & \pm 0.13 & \pm 0.11 & \pm 0.11 \\
Marbling score & 1.400 & 1.240 & 1.200 & 1.543 & 1.564 & 1.451 & 1.498 \\
Rib eye area (cm ${ }^{2}$ ) & \pm 0.30 & \pm 0.62 & \pm 0.71 & \pm 0.74 & \pm 0.75 & \pm 0.68 & \pm 0.70 \\
& 37.50 & 39.18 & 39.62 & 39.02 & 39.33 & 38.45 & 39.85 \\
& \pm 5.50 & \pm 4.73 & \pm 4.90 & \pm 4.90 & \pm 5.00 & \pm 4.92 & \pm 5.13 \\
\hline
\end{tabular}

1): $\bar{X} \pm$ S.D. 2): Data from 1973 to 1977 are cited from Taketomi et al. (1977, 1979). 3): Body weight per day of age at beginning of fattening 
Table 3. Sires with deviation value of more than 60 or less than 40 in final weight, daily gain, marbling score and rib eye area

\begin{tabular}{|c|c|c|}
\hline Traits & Deviation value & Code of sire \\
\hline Final weight & $\begin{array}{l}\text { More than } 60 \\
\text { Less than } 40\end{array}$ & $\begin{array}{l}52(70) *, 32(69), 6(65), 57(65), 9(65), 47(64), 53(62) \\
36(38), 12(35), 14(33), 34(32), 55(29)\end{array}$ \\
\hline \multirow[t]{2}{*}{$\begin{array}{l}\text { Daily gain during } \\
\text { period of fattening }\end{array}$} & More than 60 & $\begin{array}{l}47(72), 52(72), 51(68), 32(63), 49(62), 23(61), 9(60) \\
13(60)\end{array}$ \\
\hline & Less than 40 & $12(39), 42(39), 28(39), 34(38), 36(36), 55(34)$ \\
\hline \multirow[t]{2}{*}{ Marbling score } & More than 60 & $\begin{array}{l}21(70), 14(66), 55(64), 6(64), 48(63), 57(63), 2(61), \\
42(61), 17(61)\end{array}$ \\
\hline & Less than 40 & $\begin{array}{l}49(39), 24(39), 45(39), 10(38), 53(36), 52(35), 56(35) \\
29(34)\end{array}$ \\
\hline \multirow[t]{2}{*}{ Rib eye area } & More than 60 & $\begin{array}{l}4(67), 57(67), 53(66), 19(53), 21(63), 9(62), 17(61) \\
29(61)\end{array}$ \\
\hline & Less than 40 & $\begin{array}{l}51(39), 35(39), 14(38), 3(37), 24(35), 48(35), 55(33), \\
23(33)\end{array}$ \\
\hline
\end{tabular}

( ): Deviation value. $D=10 \times\left(X_{i}-\bar{x}\right) / s+50 . \quad X_{i}$ : Performance of sire $i . \quad \bar{x}$ : Average of all sires. s: Standard deviation

脂肪交雑は，1974 年と 1975 年の 2 年間で低く評洒さ れた（1.2）方，他の年次では 1.4〜1.6宗しており肥 育日数が延長しているのに対して脂肪交雑には目立った 変化は夕られない，また口ース芯面積については，年次 間の差汪ほとんど东られず 1973 年の $37.5 \mathrm{~cm}^{2}$ 岩除くと 平均值加 $39 \mathrm{~cm}^{2}$ 前後となっている。

2. 種雄牛别産肉諸形質の話価

1）牽肉諸形質についての種雄牛の偏差值

10 頭以上の肥育牛を生産した種雄牛について, 1979 年 のデータに基ゔき各種雄牛ごとの座肉形質の平均值をる とめ，さらにこれらの諸形質のうち終了時体重，1日平

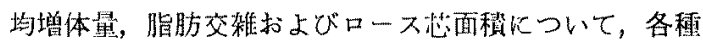
雄牛の偏差值安計算した。偏差值 60 以上と 40 末満の㮔

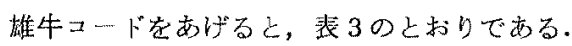

まず産肉量の多少に関係する終了㭙体重と 1 日平均增 体量についてみると，終了時体重と 1 日平均增体量とも に偏差值 60 以上家示するのは, 種雄牛コードで52, 32, 9 および 47 などがあげられ，40 以下宗すむの结 36 , 12, 34 および55などがあげられる。終了時体重と 1 日平 均増体量に関して各評価グルーブに其通したすぐれた種 雄牛が現われていることは，これら雨形質間の相関が高 い值を有することと一致している（表 7 参照）．脂肪交 雑およびロース然面積の両形質に打いて, 僱差值 60 以上 のすぐれた成績を示す種雄牛としては 17 と 57 があげら れるが, とくに57 終了時体重ですすぐれた成績を示し

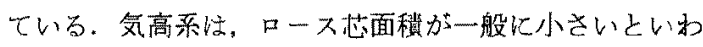
れているが3，本研究においても気高系である $51 ， 3 ４ 8$ ， 14，55 およ゙ 23 はいずれも偏差值は 40 以下を元し，田
之上らの報告8 と同じような傾向が得られた。14および 55 恉肪交雑においてはすぐれているが，口ース芯面積 では劣っている.また29は脂肪交雑では劣るが，口ース 芯面樻においてすぐれた成績を有する。これらの産肉諸 形孟についての種雄牛の漏差值は，種雄牛評価の简便な 指標として利用することができよう。

2）1日平均增体量ならびに䀝肪交雑からみた種雄牛 の評価.

本研究でとりあげた産肉諸形質のう台，肥育農家の収

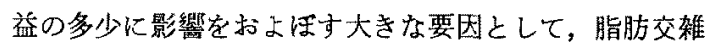
と1日平均增体量があげられる. 図1は，1979年の肥育 データから得られた全種焳牛の成縜它 1 日平均增体量と 脂肪交雅について 2 次元の座標にプロットしたものであ る. 一般に脂肪交䧴のすぐれた種雄牛は 1 日平均增体量 が低い傾向がみられ，種雄牛の平均檤による雨形質間の 相関係数は $-0.29(\mathrm{P}<0.05)$ と計算された。

偏差便 50 学境にすると 4 つの種雄牛群（A，B，C お よび D) に分けられる。すなわち，脂肪交雑および 1 日 平均增体量のいずれす偏差値 50 (平均值) 以上它有する 種雄牛群(A)，脂肪交雑にすぐれ 1 日平竡增体量が劣る， いわゆる肉質柔種雄牛群 (B)，1 日平均增体量にすぐれ 脂肪交雑加劣る增体系種雄牛群 (C), さらに幽形質とも

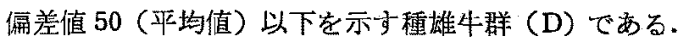
图 1 で分析された 1979 年のデー夕、にけるA群に鹰す る種雄牛としては 7 頭があげられるが、これらの種雄牛

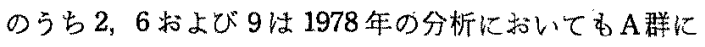
属していた。

3）産肉形質に関士る種雄牛の順位相関 


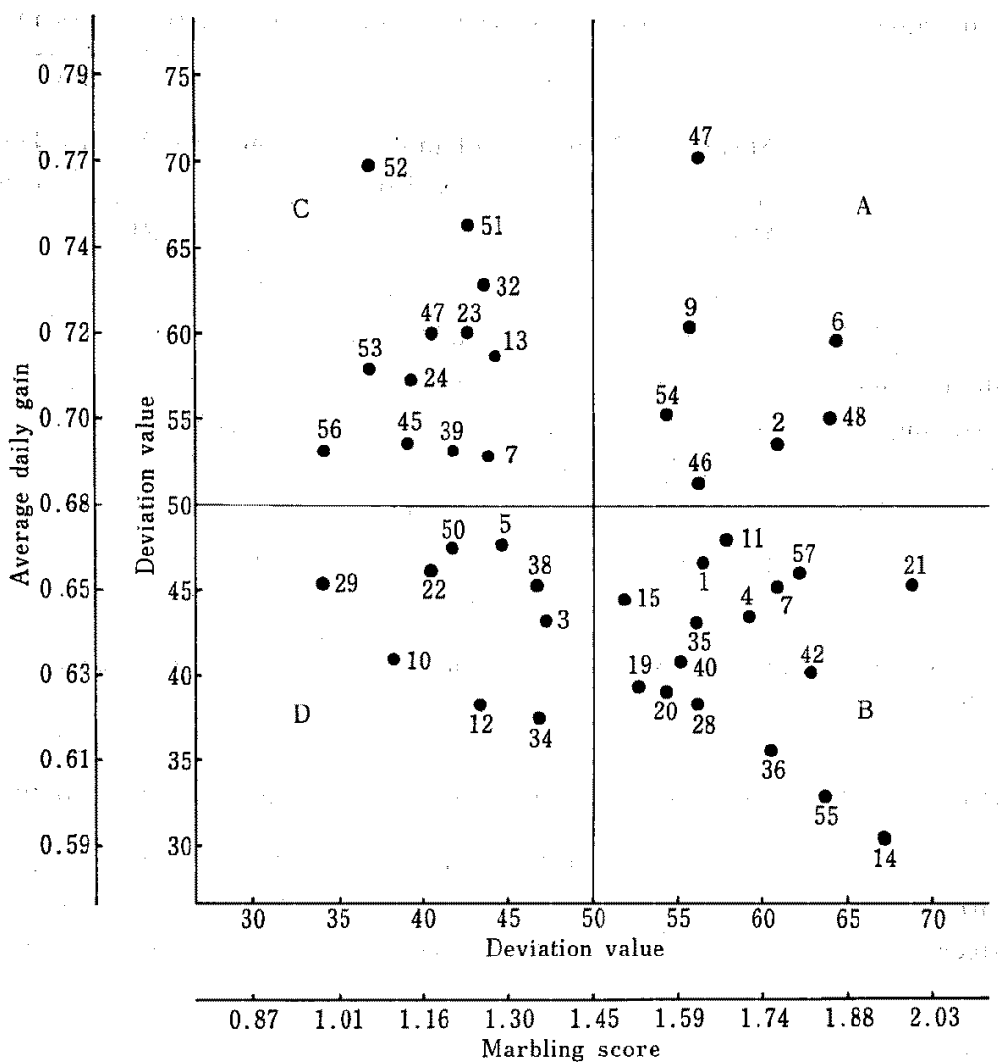

Fig. 1. Relationship between average daily gain and marbling score of sire family groups. Figures are sire codes.

表 4 は，1978 年上 1979 年に用いられた共通の種雄牛 について, 各産肉形質ごとの偏差值による順位相関係数 を計算したものである。

導人時体重, 脂肪交雑およびロース芯面積の順位相関 係数は，それぞれ $0.609 ， 0.765$ 抢よび 0.767 の高い正の

Table 4. Rank correlations of sires between 1978 and 1979

\begin{tabular}{ll}
\hline \multicolumn{1}{c}{ Traits } & \multicolumn{2}{c}{ Rank correlation $(r s)$} \\
\hline Initial weight & $0.609^{* *}$ \\
Age in days at beginning of fattening & 0.248 \\
Initial weight per age & 0.030 \\
Period of fattening & $0.446^{*}$ \\
Final weight & $0.360^{*}$ \\
Daily gain during period of fattening & 0.230 \\
Marbling score & $0.765^{* *}$ \\
Rib eye area & $0.767^{* *}$
\end{tabular}

*: $\mathrm{P}<0.05 . \quad * *: \mathrm{P}<0.01$
相関を示し，これらは1\%水準で有意であった。 また肥 育日数，終了時体重の順位相関後数は，それぞれ 0.446 , 0.360でこれらは 5\%水準で有意であった.これらの結果 から，導入归体重，脂肪交雑怙よび口一大芯面積につい ては，年次による種雄牛の評価は活は定しているすの と思われる。

4）産肉形質の種雄牛間差

各産肉形質における種雄牛間㧍よび種雄牛内の平均平 方上最小有意差を示すと，衰 5 の上おりである.いずれ

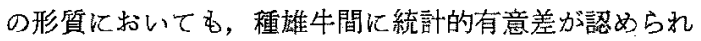
た.これらの結果は, 生産現場の産肉成績に基づき, 種 雄牛の産肉能力の評佂为可能なことを示唆するものであ 当.

3. 産肉形質の遭伝的バラメーター

1) 遗伝率

1978 年および 1979 年の肥 育デーダから推定された

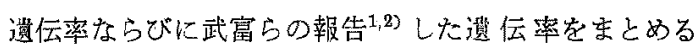
と，表6のと㧍りである。 
橋口・前田・魔島・田之上・山路

Table 5. Mean squares and D of multiple comparisons of the respective traits in 1978 and 1979

\begin{tabular}{|c|c|c|c|c|c|c|}
\hline \multirow[b]{2}{*}{ Traits } & \multicolumn{3}{|c|}{1978} & \multicolumn{3}{|c|}{1979} \\
\hline & $\begin{array}{l}\text { Mean } \\
\text { square } \\
\text { between } \\
\text { sires }\end{array}$ & $\begin{array}{l}\text { Mean } \\
\text { square } \\
\text { within } \\
\text { sires }\end{array}$ & $\begin{array}{l}\text { D of multiple } \\
\text { comparisons } \\
(5 \%)^{1)}\end{array}$ & $\begin{array}{l}\text { Mean } \\
\text { square } \\
\text { between } \\
\text { sires }\end{array}$ & $\begin{array}{l}\text { Mean } \\
\text { square } \\
\text { within } \\
\text { sires }\end{array}$ & $\begin{array}{l}\text { D of multiple } \\
\text { comparisons } \\
(5 \%)^{1)}\end{array}$ \\
\hline Initial weight & $3032.0^{* *}$ & 625.0 & $3.98 \mathrm{~kg}$ & $2817.9 * *$ & 583.5 & $3.93 \mathrm{~kg}$ \\
\hline $\begin{array}{l}\text { Age in days at beginning } \\
\text { of fattening }\end{array}$ & $3218.6^{* *}$ & 800.7 & 4.51 days & $4437.8^{* *}$ & 882.8 & 4. 84 days \\
\hline Initial weight per age & $0.04082^{* *}$ & 0.01452 & $0.019 \mathrm{~kg}$ & $0.01851 * *$ & 0.01335 & $0.019 \mathrm{~kg}$ \\
\hline Period of fattening & $20263.7^{* *}$ & 2140.2 & 7. 37 days & $10276.6^{* *}$ & 2029.7 & 7. 34 days \\
\hline Final weight & $7818.0^{* *}$ & 2167.7 & $7.41 \mathrm{~kg}$ & $6324.9^{* *}$ & 2123.5 & $7.51 \mathrm{~kg}$ \\
\hline $\begin{array}{l}\text { Daily gain during period } \\
\text { of fatteninig }\end{array}$ & $0.02779 * *$ & 0.01059 & $0.016 \mathrm{~kg}$ & $0.05077^{* *}$ & 0.01027 & $0.017 \mathrm{~kg}$ \\
\hline Marbling score & $1.33019^{* *}$ & 0.41469 & 0.102 & $2.59676^{* *}$ & 0.44779 & 0.109 \\
\hline Rib eye area & 128. $167^{* *}$ & 21.292 & $0.73 \mathrm{~cm}^{2}$ & $143.127^{* *}$ & 22.305 & $0.77 \mathrm{~cm}^{8}$ \\
\hline
\end{tabular}

**: $\mathrm{P}<0.01$. 1) : Cited from SNEDEcor, Statistical Methods. 5 th ed. p 251, The Iowa University Press, Ames, Iowa, 1965.

Table 6. Heritability estimates of the respective traits from 1973 to 1979

\begin{tabular}{|c|c|c|c|c|c|c|c|}
\hline Year & $1973^{11}$ & $1974^{1)}$ & $1975^{11}$ & $1976^{1)}$ & $1977^{1)}$ & 1978 & 1979 \\
\hline No. of sires & 19 & 24 & 18 & 17 & 28 & 45 & 44 \\
\hline No. of steers & 420 & 726 & 608 & 381 & 604 & 1449 & 1460 \\
\hline \multicolumn{8}{|l|}{ Traits } \\
\hline Initial weight & & & & & 0.57 & 0.43 & 0.42 \\
\hline Initial weight per age & 0.11 & 0.135 & 0. 182 & 0.186 & 0.50 & 0.22 & 0.04 \\
\hline Final weight & & & & & 0.58 & 0.30 & 0.23 \\
\hline $\begin{array}{l}\text { Daily gain during period } \\
\text { of fattening }\end{array}$ & 0.32 & 0.138 & 0.085 & 0.212 & 0.29 & 0.19 & 0.43 \\
\hline Dressed carcass percentage & 0.35 & 0.270 & 0.113 & 0.173 & & & \\
\hline Marbling score & 0.24 & 0.145 & 0.134 & 0.261 & 0.33 & 0.39 & 0.51 \\
\hline Rib eye area & & & & & 0.56 & 0.54 & 0.57 \\
\hline
\end{tabular}

1): Data from 1973 to 1977 are cited from TAKETOMI et al. $(1977,1979)$

分析された 7 形質のうち, 導入郝体重 $\left(\widehat{\mathrm{h}^{2}}=0.4 \sim 0.6\right)$ とロース秋面積（ $\widehat{\mathrm{h}}^{2}=0.5 \sim 0.6 ）$ は年次間で比較的安定

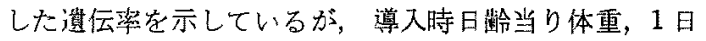
平均增体量，終了㭙体重むよび枝肉步留の推突遗伝䋈は 年次間でかなり異なる值を示している。标た，肪交雑 の遗伝率 $(0.1 \sim 0.5)$ も年次間で变動がみられるが，種 雄牛の供試頭数が增加した 1977 年からはやや安定した 遗伝率 $(0.3 \sim 0.5)$ 等示している。枝肉步留については,

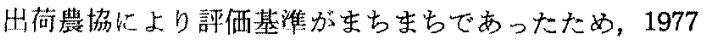
年以降は遗伝率の評価が不可能であったが, 1976 年以前 の推定值では遗伝率が低いことがうかがわれる。尔入㭙 体重については，父覞分散成分の中に子牛の飼養地域の 効果も混入している可能坐も考えられるので，今後は子
牛の飼意地域も考虑に入れた分析が必要であるう.

\section{2) 相関係数}

1979年次における産肉データに基づいて評価された各 形留間の表型相関ならびに遗伝相関を暲すると，表 7 のとおりである.

まず枝肉価格決定の大きな要区である脂肪交雑につい てみると，導入時体重ならびに尊入時日歯とはそれどれ $0.43 ， 0.34$ の遺伝相関が少ら㚘た。肥育期間の1日平均

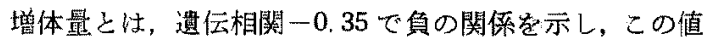
は種雄牛の平均値による相関係数 $\mathrm{r}=-0.29$ (図 1) と ほとスど等しい，つぎに增体の指整である肥育期䦗の1 日平均增体量についてみると，肥育日数とは遗伝相関で -0.79 の負の高い相関が多られ，表型相関は一0.40を示 
黑毛和種種雄牛の現場後代検定

Table 7. Correlations among seven productive traits of Japanese Black Cattle in 1979

\begin{tabular}{|c|c|c|c|c|c|c|c|c|}
\hline$\therefore \quad$ & & $A^{1)}$ & B & $\mathrm{C}$ & D & $\mathrm{E}$ & $\mathrm{F}$ & $G$ \\
\hline \multirow{2}{*}{$\begin{array}{l}\text { B: Age in days at beginning } \\
\text { of fattening }\end{array}$} & $\mathbf{P}$ & 0.333 & & & & & & \\
\hline & G & 0.909 & & & & & & \\
\hline \multirow{2}{*}{ C: Initial weight per age } & $\mathrm{P}$ & 0,481 & -0.647 & & & & & \\
\hline & $\mathrm{G}$ & -0.216 & -0.595 & & & & & \\
\hline \multirow[t]{2}{*}{ D: Period of fattening } & $\mathrm{P}$ & -0.216 & -0.268 & 0.080 & & & & \\
\hline & $\mathrm{G}$ & -0.438 & -0.322 & -0.157 & & & & \\
\hline \multirow[t]{2}{*}{ E: Final weight } & $\mathrm{P}$ & 0.216 & -0.016 & 0.191 & 0.086 & & & \\
\hline & $\mathrm{G}$ & 0.419 & 0.213 & 0.471 & -0.614 & & & \\
\hline \multirow{2}{*}{$\begin{array}{l}\text { F : Daily gain during period } \\
\text { fattening }\end{array}$} & $\mathrm{P}$ & -0.157 & -0.019 & -0.101 & -0.404 & 0.743 & & \\
\hline & $\mathrm{G}$ & 0.035 & -0.134 & 0.538 & -0.788 & 0.814 & & \\
\hline \multirow[t]{2}{*}{ G: Marbling score } & $\mathrm{P}$ & 0.024 & 0.104 & -0.075 & 0.112 & -0.007 & -0.082 & \\
\hline & G & 0.433 & 0.336 & 0.025 & 0.149 & -0.042 & -0.348 & \\
\hline \multirow[t]{2}{*}{ H: Rib eye area } & $\mathrm{P}$ & 0.058 & 0.003 & 0.046 & 0.087 & 0.357 & 0. 244 & 0. 100 \\
\hline & $G$ & -0.065 & -0.028 & -0.050 & 0.448 & 0.121 & -0.158 & 0.371 \\
\hline
\end{tabular}

1): Initial weight. P: Phenotypic correlation. G: Genotypic correlation.

したまた，終了時体重とは，遭伝相関で 0.81 と正の高 い相関がタられた．肥育期間の增体能力早期に占う指 標としての導入時日齢当り体重は，1 日平均増体量との 間に遺伝相関で 0.54 の正の相関がみられる。をた，終了 時体重との間にも0.47 の正の遗伝相関方多られた。さ さ らに, 導入時体重と終了時体重との遺伝相関および表型

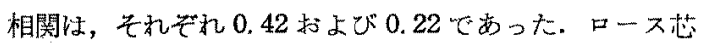
面積と肥育日数ならびに脂肪交雑との遺伝相関は, それ ぞれ 0.45 おょび0.37と評価された。

考察

1981 年度の農林水産省統計情報部蓄産統棓十出による と，鹿児島県の黑毛和種の飼養頭数は 215,700 頭に抗よ

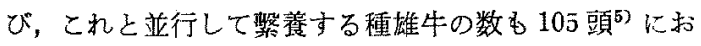
よんでいる。鹿先島県では，1967 年 4 月から 1982 年 2

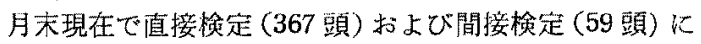
よる種雄牛の産肉能力の謰価を行ない，優复種雄牛の選 拢など多くの成果党得ている。しかし，すべての種雄牛 についての客観的評価は，施設や経費の面で制約がある のが現状である。種雄牛の飼蘶頭数が多いことは，種雄 牛の有効的利用がなされていないことを意味し，種雄牛 の飼養経費の点からきわめて不経済である。本研究は， 一般農家において肥育された黒毛和種の肥㕕データに基 ついて黑毛和種種雄牛の産肉能力の評洒学行ない, 現場 後代検定の可能性について検討を行はったあのである.

黑毛和種の産肉能力に関寸る現場後代検定の試办につ

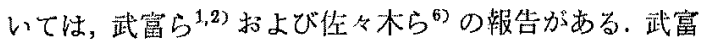

らは, 鹿児島県に括ける黑毛和種の産肉能力について分 析它行ない，産肉諸形質における種雄牛間差を明らかに し, 現場後代梌定により黑毛和種種雄牛の産肉能力の評 価が可能礼ことを明らがした、一方，茫々木らは大分 県で 1971 年から 1974 年までの 4 年間に得られた肥育牛 224 頭の肥有成績穵用いて, 種雄牛の座肉能力に対する 現場後代検定の可能性について検封它行なったが，産肉 成績の種雄牛間差を認めるに至らなかった。その理由之 しては，对象とした大分具の牛群の場合，種雄牛が鳥取 系統にかたよっていたことや産肉能力が遺伝的に似通っ ていたことなどがあげられている。

武富らの分析結果にあわせて，1978 年と 1979 年の 2 年次にわたって分析された本研究に抋いては，寺べの 産肉形質について種雄牛間差がみられたことから，一般 嶩家の肥育データに基づく現場㣪代検定が可能であるこ

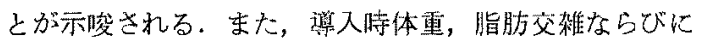
ロース芯面穑については，程雄牛の順位相関が比較的高

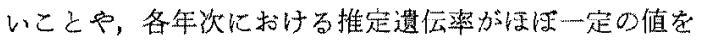
示すことから、これらの形質についての種雄牛の能力の 順位江比較的安定している。のと思われる、肥育期間の 1 日平均增体量についてい，順位相関係数が低く評価さ れたが，最近新たに著者らが分析した1979年と1980年 之の間の順位相関係数は $0.622(\mathrm{P}<0.01)$ と比較的高い 值が得られだ．このように1日平均增体量の順位相関

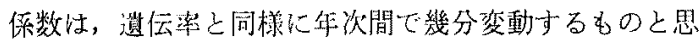
われる。

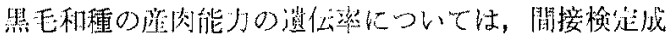




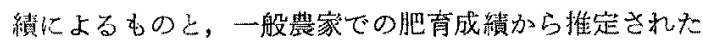

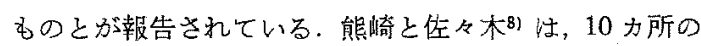
試験場から得られた間接検定のデータをもとにして，黑 毛和種の1日平均増体量，枝肉步留および脂肪交鹤の遗

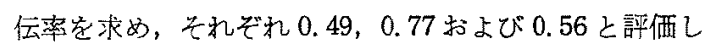

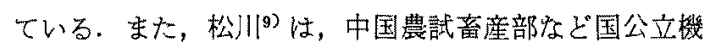
関 7 場所で行なわれた黒毛和種産肉能力間接検定の成績 から遗伝率を推定し，3形筫についてはそれぞれ0.20， 0.51 执よび 0.45 と評価している。一方, 武富らは, 一般農家の肥育成績に基ずてこれらの遗伝率を評価 し， 3 年間の平均で $0.18,0.24$ および 0.17 と報告して いるが，施設内の検定成綘による遗伝率に比較して現場 後代検定による邀伝密は低い傾向にある。本研究で得ら れた遗伝率も，武富らの報告と同様に一般に低い推定值 を示しているが，ての一因として現場検定において環境 変異が大きく評価されたためと考えられる。このような 傾向は秏牛の泌乳能力検定についても，同様の事实が認 められている ${ }^{10}$. 脂肪交雑の遙伝率について, 松川は0.45 と推定し，また口ース产面積の遗伝率は COLE and RoNNING ${ }^{11}$ にると 0.5 と報告しているが，これらの推定倠 は本研究で得られた結果とほぼ類似した值である。導入 時体重, ロース芯面稳および脂肪交雑の遗伝率は，他形 質に比べて幾分高加たこと $(0.3 \sim 0.6)$ や，年次間て 比較的安定した推定值を示したこと，さらに種雄牛間の 順位相閔が高かったことから，これらの形質は他の形䁈 に比較して種雄牛評価が容易でるることが予想される。

1 日平均增体量の種雄牛採洒については，黄伝率ならび に順位相関係数に变動がみられたこと加ら子牛の飼盖地 域や交配方式などの奻果む考虑に入れた分析を行なら必 要があらう。

脂肪交雑と 1 日平妁增体量との関係学種雄牛の平均值

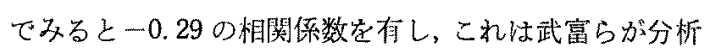
$し た ~ 3$ 年間の平均值 $(\mathrm{r}=-0.37)$ とほとんど近い值であ る、またこれら雨形質間の造伝相関ならびに父平均值間 の相関でも負の関係を示すが，このこと蕾形質を同時 に選抜することが困難であること意味し，黑毛和種の 改良において十分考虑されねばならない，今後の黑毛和 種の改良の1つの方向として，1日平均增体量と脂肪交

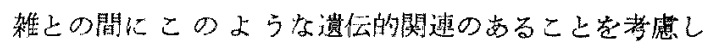
て，增体のすぐれた系統（增体系）と脂肪交雑のすぐれ 九系統 (肉質采) 学作出し，実用的に恓系統の交雑安
利用すること为溸えられよ5。

本研究では，锺雄牛の簢便な評洒法として偏差值によ 万証価定試みた，終了時体重，1日平均增体量，脂肪交 雑およびロース世面積などの単一形質を対象とした場合 には，偏差值 60 以上と 40 以下で種雄牛を評価したが， 1 日平均增体量㧍よび脂肪交雑とい52つ0座肉形質に 関しては，両形澌とすに偏差值 50 (平均梿) 以上を有主 るすぐれた種雄牛群 (A), 脂肪交雑心寸ぐれ 1 日平均增 体量方劣る肉䝷系種雄牛群 (B)，1 日平均堌体量比子く れ脂肪交雑が劣る增体系種雄牛群 (C), さらに雨形質と 6に偏差值 50 以下を示す種雄牛群 (D) 94 つに分類し た。座肉諸形質家対象乙した種雄牛の偏差值は, 種雄牛 評価の簡便な指祭として利用するととがでさよう。

本研究を行ならに当り，資料の提供をいただき稙々の ご助言をいただいた前昆児島県畜産試験場長 德重邦雄 氏，肉用牛部長 安田三郎氏ならびに全国和牛登録協会

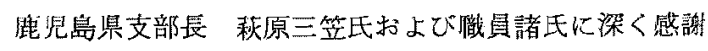
の意を表する。

\section{文献}

1）武富萬治郎・新中須浮孝・上野初夫・浜崎满洋・前 由芳實・橋口，勉・小山田 哄, 鹿大農学術報告, 27: 77-88. 1977.

2）武富荡治郎・橋口 魅・前田芳蜜・諸留辰男・小川 清彦・中西喜彦・小山田琵, 鹿大㷧学部肉用牛 種研究会調査報告, 1-21. 1979.

3) 由之上悠石・虑岛 学・山路正則 -川畑杰・德 重邦雄，康照島県畜試報告，14 号：28-78. 1982.

4)農林水産省統計情報部，蓄産統計，30-31. 農林統 評協会. 東京. 1981.

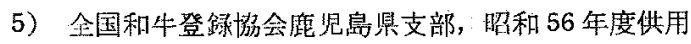
種雄牛名簿, 1-26. 1981 .

6）仵ヶ木亲之・江藤㤵一郎・向斗文雄・並河澄，日 蓄会報, 47：354-358, 1976.

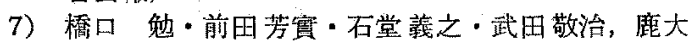

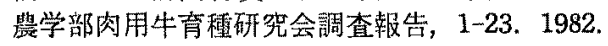

8）熊崎一雄・佐々木義之，日畜会報，43：366-373. 1972.

9）松川 正, 中国農試報告, B 15：17-25，1967.

10) Touchberry, R. W., K. Rattensten and H. ANDERSON, J. Dairy Sci., 43: 529-545. 1960.

11) Cole, H.H. and M. Ronning eds., Animal Agriculture-The Biology of Domestic Animals and Their Use by Man. 2 nd ed. 231. W. H. Freeman and Company. San Francisco. 1980. 


\title{
The Effectiveness of "On-farm Progeny Testing" on the Meat Production Performance of Japanese Black Cattle
}

\author{
Tsutomu HaShiguchi, Yoshizane MaEdA, Manabu KaSHIMA*, \\ Yuseki TANOUE* and Masanori YamaJI* \\ Faculty of Agriculture, Kagoshima University, \\ Kagoshima-shi 890 \\ *Kagoshima Prefectural Livestock Experiment Station, \\ Kokubu-shi $899-44$
}

Based on data of 3431 steers fattened by farmers in Kagoshima prefecture during 1978 and 1979, the possibilities of progeny tests on the meat production performance of Japanese Black Catthe sires were examined. Differences among the means of sire family groups were statistically significant $(P<0.01)$, in all the following traits analyzed in this study: initial weight, age in days at the beginning of fattening, initial weight per age (body weight per day of age at the beginning of fattening), period of fattening, final weight, daily gain during the period of fattening, marbling score and rib eye area. Heritabilities of initial weight, rib eye area and marbling score were calculated to be $0.4 \sim 0.6,0.5 \sim 0.6$ and $0.3 \sim 0.5$, respectively. Heritabilities of other traits were relatively low and varied from year to year. Concerning initial weight, marbling score and rib eye area, correlations between rank of sire in 1978 and in 1979 were estimated as 0.609 , 0.765 and 0.767 , respectively $(P<0.01)$. Genetic correlations among the productive traits were calculated to be: marbling score and initial weight 0.40 , marbling score and age in days at the beginning of fattening 0.30 , marbling score and daily gain -0.35 , rib eye area and period of fattening 0.45 , rib eye area and marbling score 0.37 , daily gain and period of fattening -0.79 , and daily gain and final weight 0.81 . From above results, it was recognized that a progeny test based on fattening data obtained from farmers was practicable for the valuation of a sire.

Jpn. J. Zootech. Sci., 53 (10): 656-663: 1982 